\title{
時間分解蛍光免疫測定法による カイコ前胸腺刺激ホルモンの血中濃度の測定
}

溝 口明 (名古屋大・院・生命理学)

過去 20 年以上にわたり、ホルモンの微量 定量法といえばRIAが主流でしたが、近年、 高感度の非RI 測定法の開発が進み、RIAにと って代わりつつあります。本稿では、そうし た新世代の測定法の一つである時間分解蛍免 疫測定法 (Time-Resolved Fluoroimmunoassay: TR-FIA）による昆虫の血中ホルモン濃度の測 定を紹介します。TR-FIAによるホルモン測 定は10年ほど前から報告されており、本学 会での研究発表にも数年前から登場しており ますので、ご存じの方も少なくないと思いま す。従いまして、ここでは、方法の原理や特 徵、応用等についての説明は最小限にとどめ、 昆虫の血中ホルモンの測定の実際を具体的に 紹介していきたいと思います。

デルフィアシステム : TR-FIAは、ファルマ シア社が販売するデルフィア (DELFIA) シス テムにより行なうことができます。この測定 系は96穴マイクロテストプレートを使い、 その基本操作はELISAのそれと同じですが、 トレーサーの標識体に酵素ではなくランタノ イドの一種、ユーロピウム $(\mathrm{Eu})$ を使うこと と、シグナルの測定に、時間分解測定ができ るアーカス蛍光光度計を使う点が異なりま す。時間分解測定というのは、その名のごと く、蛍光シグナルを連続的に測るのではない 所に特徵があります。1000分の 1 秒の周期 で励起光をパルス照射し、生じる蛍光をパル ス間の一定期間だけ測定して積算する方式を とっているため、励起直後の非特異蛍光が消 失した後の特異蛍光だけを測ることができ、 その結果、バックグラウンドが低く、従って、 高感度の蛍光測定ができるという仕組みで
す。そのためには巣光寿命の長い蛍光物質が 必要ですが、Euの特殊なキレートがこの要 求を満たします。この測定法を使うことによ り、RIAと同程度またははるかに高感度の測 定が可能になります。実施に当たっては、 アーカス蛍光光度計の他、プリンター、プレ 一トシェーカー、連続分注ピペットなどの機 器と専用の試薬が必要です。

デルフィアの方法は、競合法とサンドイ ッチ法の二つのタイプに大別できます。競合 法では、一定量の抗体に対してEu標識ホル モンと試料中のホルモンを競合させます。原 理は通常のRIAと同じですが、抗体を直接あ るいは二次抗体を介して固相化するため、抗 体に結合しなかった標識ホルモンの除去は、 洗浄により迅速・簡便に行なえます。競合法 は、感度においてサンドイッチ法に劣ります が、抗体が一種類しか利用できない場合や、 測定するホルモンが低分子の場合には有用な 方法です。一方、サンドイッチ法では、特殊 な例を除き、エピトープを異にする 2 種類の 抗体を必要とします。この方法では、まず、 第一の抗体をプレートに固相化し、そこに抗 原(ホルモン)とEu標識第二抗体を同時に(1 ステップ法)、あるいは順次 ( 2 ステップ法) 加えて抗原一抗体サンドイッチを形成させ、 固相に結合したEuを定量します。

カイコ前胸腺刺激ホルモン : 私は、カイコの 神経分泌ホルモン類を研究の対象としてお り、その一つである前胸腺刺激ホルモン (PTTH)の血中濃度を測定する必要に迫られ ていました。PTTHは前胸腺に作用してエク ジステロイドの合成・分泌を刺激し、昆虫の 
脱皮・変態の制御に重要な働きをする、分子 量約30kDのペプチドホルモンです。このホ ルモンは脳内のわずか 2 対の神経分泌細胞で 生産されており、そこから分泌される量は多 くは期待できませんし、小さなカイコの体か ら採取できる血液の量は僅かであり、微量の 血液を使ってホルモン濃度を測るためにも高 感度の測定法が必要でした。PTTH抗体を最 初に得た時点で、まずRIAを試みたのですが、 感度が不十分であり、より高感度の測定法が 求められました。また、RIAに必要なホルモ ンのヨード標識は、時間的にも精神的にも大 きな負担でした。そこで、超高感度の非RI 測定法の開発を模索することになり、その時、 デルフィアの存在を知った次第です。サンド イッチ法に基づくPTTHのTR-FIAの開発に は、準備期間を含め数年を要しましたが、最 近ようやく目的を達することができました。

さて、TR-FIAにより血中PTTHを測定する ためには、解決すべき 3 つの課題がありまし た。第一は抗体の作製、第二にアッセイ系の デザイン、第三が血液の前処理です。以下に、 それぞれについて説明します。

抗体の作製 : サンドイッチ法の実施には 2 種 類の抗体が必要ですが、抗体の抗原へのアフ ィニティは十分に高くなければなりません。 というのも、この測定系では、最初に形成さ れた抗原抗体複合体は、続く反応ステップと ステップ間の徹底した洗浄を通して維持され ねばならないからです。この目的にかなう抗 体は、モノクローナル抗体として、比較的容 易に得ることができます。使用する 2 種類の 抗体は、共にモノクローナル抗体でもよいで すが、一方をポリクローナル抗体とすること も可能です。我々は、リコンビナントPTTH を免疫原として、数種類のマウスモノクロー ナル抗体とウサギ抗血清を作製し、最適な組 合せを検討したところ、固相化する抗体をモ ノクローナル抗体とし、トレーサーとなる第 二抗体をウサギのポリクローナル抗体とする 組合わせがよいとの結論を得ました。いずれ
の抗体もプロテイン Aカラムによりアフィニ ティ精製して使用します。

アッセイデザイン : サンドイッチ法の基本型 を先に説明しましたが、この方法には多くの バリエーションがあり、必要に応じて改変す ることができます。例えば、第二抗体をビオ チンで標識しておいて、これを市販のEu標 識ストレプトアビジンで検出すれば、シグナ ルを増幅することができます。ビオチン標識 はEu標識に比べ、はるかに安価にできます ので、この方法には経済的にも大きなメリッ トがあります。また、第一抗体と第二抗体が 別種の動物に由来するのであれば、例えば、 第一抗体がマウス、第二抗体がウサギ由来の 場合、無標識の第二抗体を、標識した抗ウサ ギ IgG抗体で検出することもできます。イン キュベーションのステップが増えるに従っ て、手間も時間も多くかかりますが、アッセ イに要する時間は高々半日程度ですので、あ まり問題にはなりません。ここで、PTTH測 定の具体的手順を示します。まず、固相化す るマウスモノクローナル抗体を $2 \mu \mathrm{g} / \mathrm{ml}$ にな るようにPBS(pH 7.4)で希釈し、マイクロテ ストプレートの各ウエルに $100 \mu 1$ ずつ分注 します。プレートには、自家蛍光が比較的低 く抗体結合特性が良いコースター社の EIA/RIAプレートを使用しています。デルフ イア専用プレートも市販されていますが高価 です。抗体の固相化 (吸着)は、抗体溶液を

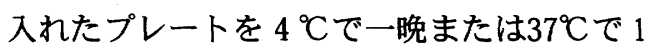
〜2時間静置するだけで完了です。洗浄液 (0.05\% Tween-20と0.9\% NaCl を含む $20 \mathrm{mM}$ リス一塩酸緩衝液、 $\mathrm{pH} 7.4)$ でプレートの各ウ エルを 5 6 回洗浄すると何時でもアッセイ を開始できます。プレートの洗净は自動洗浄 機を使ってもできますが、必需品ではありま せん。大量の洗浄液を必要とするので、むし ろ使いづらい面もあり、私は洗净瓶を使って 手作業で行なっています。各ウエルに洗浄液 を满たし、プレートシェーカーで30秒程振 とうした後、流しに捨て、新しいバッファー 
と交換する、という操作を繰り返すというも のであり、2 枚程度の処理であれば、こちら の方が便利です。洗浄後は、プレートをペー パータオルに吒きつけて残液をできるだけ除 きます。さて、抗原一抗体反応ですが、私は 1 ステップ法を採用しています。すなわち、 抗原であるホルモンと第二抗体をウエルに同 時に加えて反応させ、抗原抗体サンドイッチ を形成させます。2 ステップ法に比ベ、バッ クグラウンドがやや高くなる傾向はあります が、時間を短縮できるという大きなメリット があります。ウエルに、前処理済みカイコ血 液サンプル50 $\mu 1$ (血液50 $\mu 1$ 相当) と希釈䋧 衝液 ( $1 \%$ ウシ血清アルブミン、 $0.9 \% \mathrm{NaCl}$ 、 $0.1 \% \mathrm{NaN}_{3}$ を含む $0.5 \mathrm{M}$ トリス一塩酸緩衝液、 $\mathrm{pH} 7.8)$ で希釈したビオチン標識ウサギポリク ローナル抗体 $50 \mu 1$ を加えます。また、この 時、段階希釈した標準ホルモン $50 \mu 1$ をサン プルに代えて入れたウエルを検量線作成のた めに準備します。プレートにはパラフィルム を被せ、指で押し付けて蓋をします。インキ ユベーションはプレートシェーカーで振とう

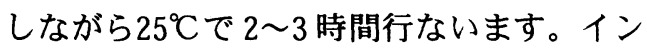
キュベーションが終わったら、洗浄液で 6 回 洗浄し、デルフィア用アッセイ緩衝液(ファ ルマシア)で希釈したEu標識ストレプトアビ ジンを $100 \mu 1$ 加えます。インキュベーショ ンはプレートシェーカー上で30分間行ない、 終了後 6 回洗净します。泡を除くため、最後 の洗浄はTween-20を含まないトリス一塩酸 緩衝液で行ないます。次いで, 増強試薬 ( アルマシア)を $100 \mu 1$ 加え、プレートシェー カーで 5〜10分間振とうすれば、あとは蛍光 光度計で測定するだけです。蛍光測定は 1 ウ エル当たり 1 秒であり、1 プレート(96サン プル)でも 2〜3 分で終わります。プログラ 厶を入れておけば、検量線の作成から定量ま で自動的に行なわれますので、アッセイ開始 から結果の入手までは 4 時間前後ということ になります。これはRIAに比べ大幅な所要時 間の短縮であり、この方法の大きな特長とな っています。しかし、最大の利点は、その最
小検出量にあります。上記の方法での検出限 界は 1 ピコグラム以下であり、この值は、 RIAの標準的な感度を凌ぎます。また、RIA と比較した場合、実験施設の制約もなく、ホ ルモンの放射標識や廃棄物の管理・処理の煩 わしさもないといった手軽さは、一度覚えた らRIAには戻れない魅力があります。

血液サンプルの前処理 : 血液中のホルモンを イムノアッセイで測定する場合、常に問題に なるのが、血液成分による測定への干渉です。 プロテアーゼを初め様々な因子が測定の邪魔 をしますが、それらは動物種や測定法により 異なりますので、個々の場合について対策を 講じる必要があります。ヒトの血中ホルモン の測定については、多くのRIAが開発されて おり、同時に干渉作用の低減が工夫されてき ました。血清アルブミンの他、アプロチニン、 EDTA、メルカプトエタノールなどの添加は その例です。しかし，これらの方法は、残念 ながら、カイコ血液による干渉を満足に抑え ることができません。また、昆虫の血液には 更に厄介な問題があります。それは、発育段 階に依存して組成が大きく変わることです。 例えば、カイコ 4 齢幼虫の血中タンパク質濃 度は約 1 パーセントですが、藏作り直前の 5 齢幼虫では数パーセントにも達します。糖や 脂質についても脱皮 - 変態に伴って大幅な量 的・質的変動が認められます。また、強力な 干渉成分であるプロテアーゼの活性も大きく 変化すると考えられます。従って、発育・変 態に伴うホルモン濃度の変化を調べる場合、 干渉因子の量的・質的変化が重大な障害にな るという訳です。こうした問題を回避するた めには二つの方法が考えられました。一つは 干渉成分の除去であり、いま一つは、反応液 中の血液の量をできるだけ少なくすることで す。当初、血中PTTH濃度についてはまった く手掛かりがなく、とりあえずPTTHを粗精 製して測ってみることにしました。その方法 はPTTHのカイコ脳からの精製法を参考にし たもので、アセトン沈澱と熱処理を組合わせ 
たものです。アセトン濃度と加熱条件 (温度 と時間)の最適な組合せを検討したところ、 血球を除去した血液に終濃度 $60 \%$ になるよ うに冷アセトンを加え、生じた沈激をアセ トンで洗净し、減圧下でアセトンを除いた のち、緩衝液に溶解して $85^{\circ} \mathrm{C}$ で 5 分間加熱 するとよい結果が得られることがわかりま した。遠心後の上清には干渉作用はほとん ごなく、PTTHの回収率は70\%以上でした。

PTTH分泌リズム：上記の方法で血液を処理 し、先に述べた方法によりPTTH濃度を測定 した結果を図 1 に示します。図から明らか なように、PTTH濃度には日周リズムがある ことがわかります。ホルモン濃度の日周変 動は、ヒトのホルモンで広く知られており 珍しくはありませんが、PTTHが毎日分泌さ れていることの発見は大きな驚きでした。 というのも、従来、PTTHは脱皮周期の間に 一度あるいは二度分泌されて、それが前胸 腺からのエクジソン分泌を刺激することに より脱皮を誘導すると信じられていたから です。PTTHが毎日同じように分泌されてい るのであれば、PTTHの前胸腺活性化機構は 根底から考え直さねばなりません。前胸腺

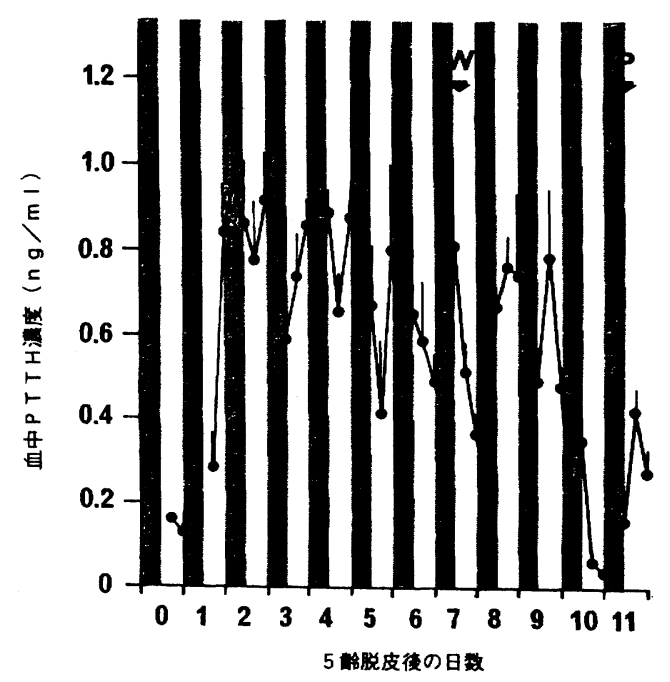

図 1 カイコ 5 数幼虫における血中PTTH湴度の 变化（TR-FIA法により測定した。W：ワン タリングの開始 $\mathrm{P}$ : 蛹化)
の活性化にはPTTHの綝返し刺激が必要か、 あるいは特定の時期の分泌のみが有効なの か、もし後者であればPTTHが繰返し分泌さ れる意味は何か。PTTH分泌リズムの発見は こうした重要な問題を提起するものです。

測定法の改良 : さて、こうして実際にPTTH 濃度を測ってみると、予想よりも高濃度で存 在することがわかりました。とすると、測定 に使う血液量を減らすことができると考えら れます。血液量が少なければ干渉作用も小さ くなると期待できます。そこで，血液量を減 らし、前処理も簡素化してみました。また、 同時に測定感度を高める工夫をしました。以 下がその新しい方法です。血球を除去したカ イコの血液50 $\mu 1$ を $150 \mu 1$ の脱イオン水で希 釈して沸騰水中に 1 分間置いた後、直ちに冷 却し、遠心後の上清 $50 \mu 1$ を測定サンプルと します。このサンプルは、血液 $12.5 \mu 1$ 相当 を含んでいます。この熱処理により、20〜 $30 \%$ のTTHが失われますが、大半のタンパ ク質を除去できますし、最強の干渉成分であ るプロテアーゼを失活させることができま す。マウスモノクローナル抗体を固相化した ウエルに、希釈緩衝液で希釈したウサギ抗体 $200 \mu$ とサンプル50 4 1を同時に加えて、2〜 3 時間インキュベートします。反応液の総量 を増やしたのは、血液が占める割合を減らす ことにより、干渉作用とそのばらつきを最小 限にするためです。ここでは、ビオチン標識 していない第二抗体を使っていますが、この 抗体はビオチン標識抗ウサギ IgG抗体で検出 します。その結果、シグナルを増幅すること ができます。この第三抗体はEu標識ストレ プトアビジンと同時に加えてやればよく、イ ンキュベーションの回数を増やす必要はあり ません。但し、インキュベーション時間は 1 時間とします。あとの操作は先に述べた方法 と同じです。この方法を使った場合、測定の 下限は0.1ピコグラムとなり、干渉作用もほ とんど認められません。こうして、現在では、 より少量のサンプルを使って、より簡便に 
PTTHが測定できるようになっています。

以上に、カイコPTTHの測定の例を通して TR-FIAを紹介してきましたが、この方法が、 測定感度、簡便性、迅速性、安全性のいず れの点においても、RIAに勝ることがおわか りいただけたかと思います。新しくTR-FIA を始めたいという方には、ファルマシアバ
イオテクの小冊子「ランタノイド標識を用 いた時間分解蛍光測定」が参考になると思 います。この冊子には、デルフィアを利用 した研究の論文リストが付けられています。 アッセイのデザインや干渉因子対策などに ついては、EIAの一般的解説書が役立つと思 います。

\section{日本比較内分泌学会 編 / 全10巻 ホルモンの生物科学}

\section{1 比較内分泌学序説} 山本 清編

180頁 $\cdot 2884$ 円

\section{2 ホルモンの生産と分泌}

見上晋一編

300 頁 · 3708円

3 ステロイドホルモンの生物化学 玉置文一編

260 頁・3708円

\section{4 ホルモンと生殖 I}

一性と生殖リズム

新井康允・小林英司 編

310 頁 $\cdot 3090$ 円

\section{5 ホルモンと生殖 I}

一その相関と作用機構 木川源則・大島 清 編
6 ホルモンと生殖 III 一生殖現象の制御 笹本修司・会田勝美 編 270 頁 $\cdot 4600$ 円

\section{7 ホルモンと水・電解質代謝} 小林英司・平野哲也 編

210 頁

\section{8 行動とホルモン}

大西英爾・川島誠一郎 編

250 頁 $\cdot 3502$ 円

9 性分化とホルモン

田名部雄一・川島誠一郎 編 200 頁・3090円

10 ペプチドホルモン

石居 進他編

180 頁 $\cdot 3200$ 円

A 5 判／学会出版センター刊（定価は税込みです.） 